\title{
First record of Lagocephalus guentheri Miranda Riberio 1915 (Tetraodontiformes: Tetraodontidae) from the West Coast of India
}

\author{
Subhrendu Sekhar Mishra ${ }^{1 *}$, Priyankar Chakraborty ${ }^{2}$, Saresh Chandra Saren ${ }^{1}$ and Anwesha Sengupta ${ }^{1}$ \\ 'Marine Fish Section, Zoological Survey of India, Kolkata - 700016, West Bengal, India; \\ subhrendumishra@gmail.com \\ ${ }^{2}$ Bharati Vidyapeeth Institute of Environment and Education Research, BVU (Deemed), Pune - 411043, \\ Maharashtra, India
}

\begin{abstract}
A puffer fish, Lagocephalus guentheri Miranda Riberio, 1915, is recorded for the first time from the west coast of India. Three individuals were collected from three different states, Gujarat, Maharashtra and Kerala, with other materials. Brief notes on diagnostic characters of the species and distinction between all species of the genus Lagocephalus in form of a working key to species is presented in this paper.
\end{abstract}

Keywords: First Record, Gujarat, Identification Key, Kerala, Lagocephalus, Maharashtra

\section{Introduction}

The family Tetraodontidae is a divergent group of fishes consisting of 190 valid species and 29 genera (Eschmeyer and Fong, 2018; Froece and Pauly, 2018), of which 8 genera and 32 species occurs in Indian waters (Gopi and Mishra, 2015). Puffer fishes of the genus Lagocephalus Swainson 1839 (Tetraodontiformes: Tetraodontidae) are circumtropical in distribution (Matsuura and Satoh, 2016). Of the nine species in this genus currently accepted as valid (Eschmeyer et al., 2018), 7 are reported from Indian waters till date. Of the nine species in this genus currently accepted as valid (Eschmeyer et al., 2018), 7 are reported from Indian waters till date. Puffer fishes belonging to the genus Lagocephalus are distinguished in having the following characters: a broad silvery-white band from below the eye, running horizontally ending at the caudal-fin base (faded on preservation); presence of a skin fold extending laterally on the ventral part of the body from the chin to the caudal peduncle; two lateral lines one ventrally and one laterally joining on caudal peduncle; nostril with two openings (Matsuura and Satoh, 2016).

Although the genus has been recognized from all tropical and subtropical seas (Matsuura and Satoh, 2016), the delineation of one species from the other is often confusing. Most species are cryptic which makes them very difficult to differentiate. Also due to migration and shipping operations such as ballast water exchange, Lagocephalus species have been occurring outside their native ranges (Fricke et al., 2012; Farrag et al., 2014) which add to the difficulty in identifying them.

In the present study, Lagocephalus guentheri Miranda Riberio, 1915 is recorded from Jamnagar (Gujarat), Sindhudurg (Maharashtra) and Vizhinjam (Kerala) on the western coast of India, for the first time. A working key for all the nine known valid species belonging to the genus Lagocephalus is attempted by review of literature and used here for identifying the collected specimens.

\section{* Author for correspondence}




\section{Material and Methods}

The identification key for all the species belonging to the genus Lagocephalus was prepared by reviewing literature and the same key, given hereunder, is used to identify the specimens that were collected. The specimens were preserved and deposited at Zoological Survey of India (Z.S.I), Kolkata. Table 1 represents the morphometric and meristic data from the specimens. Counts and measurements follow Decker (1975) and were done using digital callipers to the nearest millimetre. The preserved specimens were photographed and identified following the identification key prepared.

\section{Key to Lagocephalus species}

1a. Spinules absent on the dorsal surface between eye and dorsal fin... .2

1b. Spinules present on the dorsal surface between eye and dorsal fin. . .4

2a. Dorsal fin with 13-15 rays; gill opening not black; distinct dark spots on sides near pectoral fin base; lower third of pectoral fin whitish....L. lagocephalus

2b. Dorsal fin with 16-19 rays; gill opening surrounded by a black rim; no distinct dark spots around pectoral fins; lower third of pectoral fin dusky, not whitish 3

3a. Anal fin with12-14 rays; caudal fin ray 11; caudal fin lunate, upper lobe of caudal fin longer than lower lobe

L. laevigatus

3b. Anal fin with 9-12; caudal fin ray 9-10; caudal fin slightly concave, upper and lower lobes of equal length

L. inermis

4a. Spinules on back extending to or beyond dorsal fin origin . .5

4b. Spinules on back not extending to dorsal fin origin, halfway through interorbital region to dorsal fin base.

5a. Anal fin rays 11-13; dorsal surface of body without black spots L. lunaris

5b. Anal fin rays 8-11; dorsal surface of body with distinct scattered black spots

6b. Irregular brown to grey or black spots of various shapes and sizes dorsally; raised skinfold present along lower side of caudal peduncle L. suezensis

6a. Regular black spots on body dorsally almost of equal size; no raised skinfold along lower side of caudal peduncle

L. sceleratus 7a. Caudal fin lunate without medial posterior extension, upper rays relatively projected than lower rays; dorsal two third of caudal fin dark yellow and ventral one third white and without white tips to dorsal and ventral lobes; no dark marking on the dorsal side of caudal peduncle.

L. spadiceus (Syn. L. wheeleri)

7b. Caudal fin emarginated (often doubly), rays at middle longer in live; caudal fin dark, tips of caudal lobes distinctly white.

8a. Pectoral fins pale; a dark patch on the dorsal side of caudal peduncle

L. guentheri

8b. Pectoral fins dusky; no dark patch on the dorsal side of caudal peduncle. L. cheesemanii (Syn. L. gloveri)

\section{Results}

\section{Taxonomic account}

The genus Lagocephalus Swainson, 1839 belongs to the Family: Tetraodontidae Bonaparte, 1832 of the Order: Tetraodontiformes, Berg, 1940. They are primarily marine fishes but also found in brackish waters. There are 9 valid species of Lagocephalus of which 6 species has been reported from Indian waters.

\section{Lagocephalus guentheri Miranda Riberio, 1915}

1915. Lagocephalus guntheri Miranda Ribeiro, Arquivos do Museu Nacional de Rio de Janeiro, 17: Tetrodontidae p. 5 (Type locality: stated to be 'Brazil', but probably erroneous. The name ' $g$ uentheri' is treated as correct by subsequent authors).

Materials examined: ZSI F 11746/2, 1 ex, 83.9 mm SL, Jamnagar, Gujarat, 3/x/2016, S.C. Saren; ZSI F 12487/2, 1 ex, $73.6 \mathrm{~mm}$ SL, Chivala Beach, Malvan, Sindhudurg, Maharashtra, 3/ix/2017, S.C. Saren; ZSI F 10765/2, 1 ex, 190 mm SL, Vizhinjam Harbour, Kerala, 2/x/2012, A. Gokul and Party.

Description: Dorsal rays: 12-14; pectoral rays: 17-18; anal rays: 11-12; body elongate with a broad head and no spots. A patch of spinules present on back from front of interorbital region, that doesn't extend to dorsal fin origin, but only up to halfway through interorbital region to dorsal fin base. Ventral spinules begin from below nostrils and ending before the anus. Dorsal half of body greyish 
black with several black bands dorsally; body flanks silvery white in colour; a distinct black marking on the dorsal side of the caudal peduncle. Caudal fin dark brown to black in color, tip of the lobes white. Dorsal, pectoral and anal fins pale (Figure 1). Proportional measurements of body parts are given in Table 1 .
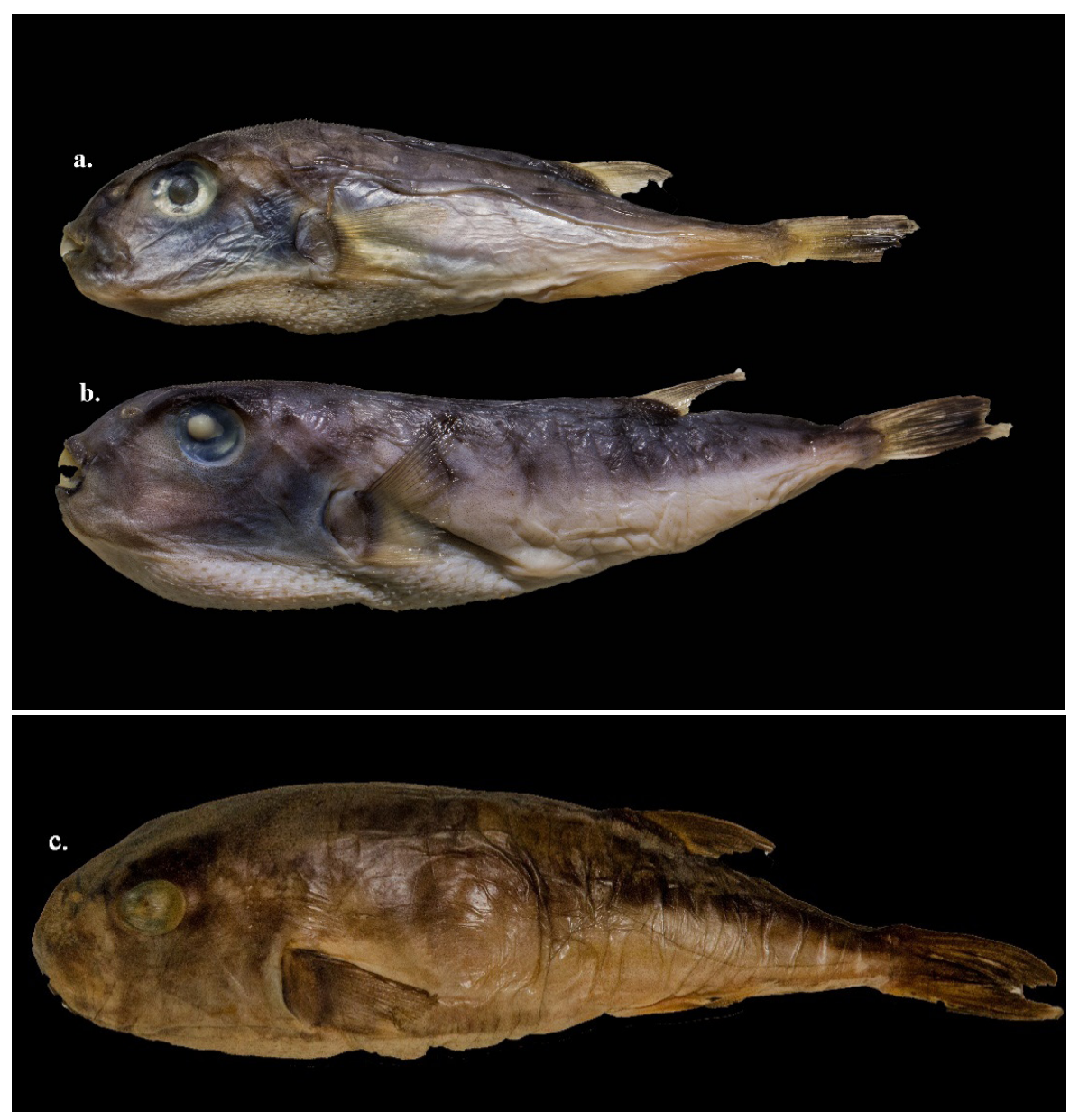

Figure 1. Lagocephalus guentheri Miranda Riberio, 1915 a. from Maharashtra (F 12487/2), 73.6 mm SL b. from Gujarat (F 11746/2), 83.9mm SL. c. from Kerala (F 10765/2), 190 mm.

Table 1. Proportional measurements of the specimen at ZSI

\begin{tabular}{|l|c|c|c|}
\hline Characters & $\begin{array}{c}\text { Maharashtra specimen } \\
(\mathbf{F ~ 1 2 4 8 7 / 2 )}\end{array}$ & $\begin{array}{c}\text { Gujarat specimen } \\
(\mathbf{F ~ 1 1 7 4 6 / 2})\end{array}$ & $\begin{array}{c}\text { Kerala specimen } \\
(\mathbf{F ~ 1 0 7 6 5 / 2})\end{array}$ \\
\hline Standard length & $73.6 \mathrm{~mm}$ & $83.9 \mathrm{~mm}$ & $190 \mathrm{~mm}$ \\
\hline Max body depth in SL & 3.4 & 3.4 & 3.2 \\
\hline Pre-dorsal length in SL & 1.4 & 1.5 & 1.4 \\
\hline Pre-pectoral length in SL & 3.1 & 2.6 & 2.6 \\
\hline Pre-anal length in SL & 1.5 & 1.4 & 2.9 \\
\hline Head length in SL & 3.1 & 3.1 & 11.4 \\
\hline Eye diameter in SL & 10.8 & 11.1 & 6.0 \\
\hline Pre-orbital length in SL & 6.2 & 7.5 & 12 \\
\hline Dorsal fin rays & 14 & 12 & 13 \\
\hline Anal fin rays & 11 & 12 & 17 \\
\hline Pectoral fin rays & 17 & 18 & \\
\hline
\end{tabular}


Distribution: Indo-West Pacific: Persian Gulf, southern Oman, India, Indonesia, north-western Australia, the South China Sea and probably Japan (Froese and Pauly, 2018); also from Red Sea (Matsura et al., 2011) and Mediterranean Sea (Farrag et al., 2016).

\section{Discussion}

Lagocephalus guentheri Miranda Riberio, 1915 is similar to Lagocephalus spadiceus (Richardson, 1845) which is also found in the region and possesses almost similar color pattern. But, can be distinguished from the former by observing the caudal fin which is lunate without any medial posterior extension (observed only in fresh specimens) and the upper $2 / 3$ of caudal fin yellow and lower $1 / 3$ white in colour. In preserved specimens, Lagocephalus guentheri Miranda Riberio, 1915 has an almost black caudal fin with white tips whereas Lagocephalus spadiceus (Richardson, 1845) has a dusky caudal fin with a black midline. Though cryptic, the two species can be distinguished between themselves. Although Randall (1995) reported difference in the spinule patch between the two species, however, Matsuura (2010) observed great level of variation in the spinule patch on the back of Lagocephalus spadiceus which makes it difficult to distinguish both species based on the shape of spinule patch.

Rao et al. (1992) reported Lagocephalus guentheri from Andamans as first record from Indian waters. Sujatha and Padmavathi (2015) probably the first to record L. guentheri from peninsular Indian coast and comments that this is the most common species in bycatch from Visakhapatnam in almost all kind of fishing gear. However, they clearly indicate their identification was based on checking by hand and there was no mention of colour pattern. The report by Barman et al. (2007) for Odisha and Barman et al. (2011) for Tamil Nadu shows the occurrence of L. spadiceus only, but not L. guentheri. Kaleshkumar et al. (2016) recently reported L. guentheri based on morphological and molecular characteristics. Probably due to recent record of this species from mainland coast, Hardy et al. (2014) not included India as a native country of occurrence for $L$. guentheri. However, Randall (1995) mentioned its occurrence along Indian coast. Distribution of all species of Lagocephalus from Indian coast is provided hereunder for a clear understanding (Table 2).

Puffer fish belonging to the family Tetraodontidae and order Tetraodontiformes were not favoured as edible items in India for the presence of the toxin; tetrodotoxin which makes it the second most toxic vertebrate in the world (Keiichi et al., 1998). Large scale destruction of fishing gear by puffer fishes has been recorded along the Konkan Coast, Maharashtra and Lagocephalus spadiceus was found to be the main culprit (Naik et al., 1998). They were considered as a menace by fishermen in Kerala because they would cut through their gear and devour the catch especially cephalopods (Pillai, 2009) But, in recent years the fish is found edible and is caught with regularity. Species like Lagocephalus inermis (Temminck and Schlegel) and Lagocephalus lunaris (Bloch and Schneider, 1801) constitutes the bulk of the catch. But, there can be equal chances of other Lagocephalus species being caught since identification is often cumbersome. The second author during his visit to the Sundarbans, came

Table 2. Distribution of Lagocephalus species in Indian waters

\begin{tabular}{|c|c|c|c|c|c|c|c|c|c|c|}
\hline Species & 1 & 2 & 3 & 4 & 5 & 6 & 7 & 8 & 9 & 10 \\
\hline 1. Lagocephalus guentheri Miranda-Ribeiro, 1915 & + & -- & -- & + & + & + & -- & + & + & -- \\
\hline 2. Lagocephalus inermis (Schlegel, 1850) & + & + & -- & + & + & + & + & + & -- & -- \\
\hline 3. Lagocephalus lagocephalus (Linnaeus, 1758) & -- & -- & -- & + & -- & -- & -- & -- & -- & + \\
\hline 4. Lagocephalus lunaris (Bloch and Schneider, 1801) & + & + & + & + & + & + & + & + & -- & -- \\
\hline 5. Lagocephalus sceleratus (Gmelin, 1789) & + & + & -- & + & -- & + & -- & -- & -- & -- \\
\hline 6. Lagocephalus spadiceus (Richardson, 1845) & -- & -- & + & + & + & + & + & + & -- & -- \\
\hline 7. Lagocephalus suezensis Clark\& Gohar, 1953 & -- & -- & -- & -- & + & -- & -- & -- & -- & -- \\
\hline
\end{tabular}

1. Andaman and Nicobar Islands; 2. West Bengal; 3. Odisha; 4. Andhra Pradesh; 5. Tamil Nadu; 6. Kerala; 7. Karnataka; 8. Maharashtra; 9. Gujarat; 10. Lakshadweep Islands. 
across the fact that puffer fishes though toxic is consumed by the locals in certain places. The locals have a special preparation for the fish where they remove certain body parts to avoid poisoning. But, occasional deaths have occurred though unreported.

The present report provides the first record of Lagocephalus guentheri Miranda Riberio, 1915 from the west coast of India, from the states of Gujarat, Maharashtra and Kerala.

\section{Acknowledgements}

The authors are thankful to Dr. Kailash Chandra, Director, Zoological Survey of India (Z.S.I.), Kolkata and Dr. L. Kosygin Singh, Scientist-D, Fish Division, Z.S.I., Kolkata for providing permission and working facilities. The second author would like to thank Dr. Kranti Yardi, Bhararti Vidyapeeth Institute of Environment Education and Research, Pune.

\section{References}

Barman, R.P., Mishra, S.S., Kar, S., Mukherjee, P. and Saren, S.C. 2007. Marine and estuarine fish fauna of Orissa. Rec. zool. Surv. India, Occ. Paper No., 260: pp. 1-186.

Barman, R.P., Mishra, S.S., Kar, S., Mukherjee, P., and Saren, S.C. 2011. Marine and Estuarine Fish. Fauna of Tamil Nadu, State Fauna Series 17 (Part 2): 293-418 (Zoological Survey of India, Kolkata).

Dekkers, W.J., 1975. Review of the Asiatic freshwater puffers of the genus Tetraodon Linnaeus, 1758 (Pisces, Tetraodontiformes, Tetraodontidae). Bijdragen tot de Dierkunde, 45: 87-142.

Eschmeyer, W.N. and Fong, J.D. 2018. Species by family/subfamily. Available from: http://researcharchive.calacademy.org/research/ ichthyology/catalog/SpeciesByFamily.asp (accessed 10Mar 2018).

Eschmeyer, W.N., Fricke, R. and van der Laan, R. (eds). 2018. Catalog of Fishes: Genera, Species, References. Available from: http:// researcharchive.calacademy.org/research/ ichthyology/catalog/fishcatmain.asp Electronic version accessed $10 \mathrm{Mar} 2018$.

Farrag, M.M.S., Osman, A.G.O., Akel, E.H. Kh. and Moustafa, M.A. 2014. Catch and effort of night purse seine with emphasize to age and growth of lessepsian Etrumeus teres (Dekay, 1842), Mediterranean Sea, Egypt. Egyptian Journal of AquaticResearch, 40: 181-190, http://dx.doi.org/10.1016/j.ejar.2014.06.003

Farrag, M., El-Haweet, A.A., and Moustafa, M.A. 2016. Occurrence of pufferfishes (Tetraodontidae) in the eastern Mediterranean, Egyptian coast-filling in the gap. BioInvasions Record, 5(1): 47-54.

Fricke, R., Golani, D. and Appelbaum-Golani, B. 2012. First record of the Indian Ocean anchovy Stolephorus insularis Hardenberg, 1933 (Clupeiformes: Engraulidae) in the Mediterranean. BioInvasions Records, 1: 303-306. http://dx.doi.org/10.3391/bir.2012.1.4.11

Froese, R. and Pauly, D. (Editors). 2018. Fish Base. World Wide Web electronic publication. www.fishbase.org, version (02/2018).

Gopi, K.C. and Mishra, S.S. 2015. Diversity of Marine fish of India. In, Venkataraman, K., Sivaperuman, C. (Eds.), Marine Faunal Diversity in India: Taxonomy, Ecology and Conservation, Academic Press, Elsevier, Oxford, U.K.: 171-193. DOI: 10.1016/B978-012-801948-1.00012-4.

Hardy, G., Leis, J.L., Harwell, H., Jing, L., Liu, M. and Shao, K. 2014. Lagocephalus guentheri. The IUCN Red List of Threatened Species 2014: e.T193718A2266028. http://dx.doi.org/10.2305/IUCN.UK.2014-3.RLTS.T193718A2266028.en. Downloaded on 06 March 2018.

Kaleshkumar, K., Rajaram, R., Vinothkumar, S., Ramalingam, V. and Meetei, K.B. 2016. DNA barcoding of selected species of pufferfishes (Order: Tetraodontiformes) of Puducherry coastal waters along south-east coast of India. Indian J. Fish., 62(2): 98103.

Keiichi, M. and Tyler, J.C. 1998. Paxton, J.R. \& Eschmeyer, W.N. ed. Encyclopedia of Fishes. Academic Press, San Diego: $230-231$.

Matsuura, K. 2001. Ostraciidae, Aracanidae, Triodontidae, Tetraodontidae. In: Carpenter KE, Niem V (eds), Species identification guide for fishery purposes. The living marine resources of the Western Central Pacific. Vol 6. Bony fishes part 4 (Labridae to Latimeriidae). FAO, Rome: 3948-3957.

Matsuura, K., Golani, D., Bogorodsky, S.V. 2011. The first record of Lagocephalus guentheri Miranda Ribeiro, 1915 from the Red Sea with notes on previous records of L. lunaris (Actinopterygii, Tetraodontiformes, Tetraodontidae). Bull. Natl. Mus. Nat. Sci.,Ser A, 37:163-169

Matsuura, K. 2010. Lagocephalus wheeleri Abe, Tabetaand Kitahama, 1984, a junior synonym of Tetrodon spadiceus Richardson, 1845 (Actinopterygii, Tetraodontiformes, Tetraodontidae). Memoirs of the National Museum of Nature and Science, (46): 39-46.

Matsuura, K. and Satoh, T.P. 2016. Redescription of Lagocephalus cheesemanii (Clarke 1897), a senior synonym of Lagocephalus gloveri Abe and Tabeta 1983, based on morphological \& genetic comparisons (Actinopterygii: Tetraodontiformes: Tetraodontidae). Ichthyological Research, 64(1): 104-110

Naik S D. and Jalihal D.R., 1998. Biological observations on the pufferfishes of South Konkan coast with special reference to the net damaging species; L. spadiceus (Osteichtyes, Tetraodontidae). Indian J. Mar. Sci., 27: 426-432. 
Pillai S.K. 2009. Lagocephalus inermis catch at Kollam - a new source of income to fishermen. Mar. Fish. Info. Serv., T \& E Ser. No 201: 27.

Randall J. E. 1995. Coastal fishes of Oman. Crowford House Publishing Pty. Ltd., Bathurst, Australia.439 pp.

Rao D.V., Kamla Devi and Rajan P.T. 1992. New records of Tetraodontiformes fishes from Andaman and Nicobar Islands. J. Andaman Sci. Assoc., 8(2): 115-120.

Sujatha K. and Padmavathi P. 2015; Taxonomy of Puffer fish (Pisces: Tetraodontidae) represented in the catches of Visakhapatnam, central eastern coast of India. J. Mar. Biol. Assoc. India, 57(2) pp. 95-104, doi: 10.6024/jmbai.2015.57.2.1798-14. 